\title{
TRAINING AS DETERMINER OF COMPETITIVE POWER AND HUMAN RESOURCES
}

\author{
Arrasyid Muhammad lqbal ${ }^{\star}$, Master Student \\ Amaliyah Amaliyah \\ Department of Economics and Business, University of Trilogi, Indonesia \\ *E-mail: iqbal.arrasyid@gmail.com
}

\begin{abstract}
The urgency of human resource development is a key factor in winning global competition, which has the consequence of increasingly intense competition amid uncertainty, this strategic step should receive full support from all stakeholders Strengthening human resources towards superior human beings has a close correlation with increased work productivity, in winning competition amid rapid changes in the world of business, political economy and culture. Therefore, the choice of development strategy with the main focus on human resource development is very appropriate to answer the challenges for Indonesia. The purpose of this paper is to describe something that can be done to create Indonesian human resources that are competitive in the global era. This study includes qualitative research with a positive paradigm, namely research conducted by analyzing the condition of human resources in Indonesia economically and more focused on the condition of natural objects where researchers function as key instruments. Data analysis is carried out using the inductive approach by always emphasizing more on meaning rather than generalization. The literature review presented in this study is important to deepen the research. The results of this study found that Indonesia urgently needs superior human resources to navigate the era of globalization due to the industrial revolution 4.0, where it requires intelligent activities, intelligent services, and innovative products. Because, there will be many types of jobs that will be affected by artificial intelligence and automation. In the future, competing competencies and capabilities from human resources will be the main agenda of company leaders to face the globalization era that continues to develop as it is today. Then to be able to create and shape superior and quality Indonesian human resources can be done by developing character education.
\end{abstract}

\section{KEY WORDS}

Human Resources, Competitiveness, Global Era, Education

Development of Human Resources (HR) began in 2019 and subsequently became the main strategy for the development of the Indonesian nation in subsequent periods. The urgency of human resource development is a key factor in winning global competition, which has the consequence of increasing competition amid uncertainty, this strategic step should receive full support from all stakeholders (Sugiarto, 2019).

Strengthening human resources towards superior people has a close correlation with increasing work productivity, in winning competition amid rapid changes in the world of business, political economy and culture. Therefore, the choice of development strategy with the main focus on human resource development is very appropriate to answer challenges for Indonesia, bearing in mind that Indonesia is currently in the period of the Asean Economic Community (AEC) and the Industrial Revolution 4.0 which demands skilled and superior Indonesian human resources to have high competitiveness so that it has a contribution in nation building (Sugiarto, 2019).

Therefore, for now and in the future, competent human resources will become a necessity for every business person in Indonesia when he wants to compete in the global market. This condition will encourage massive transformation at all levels and business units 
because every business person can enter other countries and market their products or services easily, bearing in mind that there is no longer any real boundaries so that the professionalism of each business becomes a highly prioritized actor as in many business decision-making. and continuous innovation (Tayibnapis, et al., 2018).

One of the determinants to be able to innovate continuously and sustainably is the readiness of the business world in building and preparing superior and global quality human resources, in the sense of having talents with high competency standards in their respective fields and having strong characters who can compete at the global level. Indonesia is in dire need of superior human resources as the basis for capital, given the technological changes that marked the industrial revolution 4.0 has changed the political and economic map which has caused many changes in the elements of the world of work and business on a systemic and automatic basis (Tayibnapis, et al., 2018).

Automation will indeed be able to delete old jobs, but will also be able to encourage the birth of new jobs. Automation not only provides compensation for job loss, but can also increase productivity, reduce production costs, and increase domestic demand to replace job losses due to technological advancements, including the emergence of new professions. Therefore, a study related to how to create competitive Indonesian human resources in the global era needs to be done.

The concept of competitiveness is generally associated with the concept of comparative advantage, which has supporting elements of the production process that enable one country to attract investors to invest in their countries, not to other countries. The connotation of advantage here is a situation that allows investors to reap the maximum benefit. For example, by providing cheap land, cheap labor costs, and supply of raw materials that are guaranteed to be sustainable with cheaper prices than prices offered by other countries. That is, the strength of capital and technological excellence are key determinants of increasing competitiveness (product sales) of a country. Unfortunately when the nations of the world begin to embark on a new era, developing countries (including Indonesia) are generally weak in these latter two elements. Through this weakness the interests of developing countries are controlled by the interests of developed countries. This means that in terms of the interests of developing countries, the concept of comparative advantage is more correctly read as comparative disadvantage (Imawan, 2002).

Human resources is a process of improving the quality or ability of humans in order to achieve a nation's development, while micro development of human resources is a process of planning education and training and management of personnel or employees to achieve optimum results. Despite the increase in the resources of the reform apparatus through the strategy learning organization. This can be understood because often the training that is obtained does not match the needs needed (Hasibuan, 1990).

Human resources (HR) have a central position in realizing development performance, which places humans in their function as resources in development. In this context, human prices and values are determined by the relevance of their construction to the product process. Human quality is programmed in such a way as to be in accordance with the demands of development or the demands of society. The existence of the Indonesian nation in the midst of the current global era will be influenced by the ability of Indonesian human resources, especially those characterized by the ability to master science and technology (Almasri, 2016).

The nature of human resources in every organization or company, especially in educational institutions, requires the existence of human resources as workers. Therefore, what is meant by human resources is labor in an organization. From this opinion it is clear that human resources are workers who occupy a position or people who have the responsibility to carry out tasks or work in a particular organization (Almasri, 2016).

Competitiveness is defined as the ability possessed in creating and maintaining an environment of sustainable corporate competitiveness. Martens defines competitiveness as a 
disposition to try to get satisfaction when comparing results with eligibility standards. In this definition, competitiveness is seen as achievement behavior (achievement behavior) in the context of competition, through social evaluation as a key component (Weinberg \& Gould, 2011).

Workers are human beings who have intelligent resources, not resources, assets, or factors of production that are ready to be used. Workers are also interpreted as workers who work in the employment relationships of employers by receiving wages (Hartanto, 2009). A productive worker will always try to improve the effectiveness of his work, and this will have an impact on the existence of products or services that have high competitiveness in the market. If workers work with high productivity, it will produce high competitiveness as well (Aroef \& Djamal, 2009).

Thus, worker competitiveness (worker competitiveness) is the ability of workers to maintain and create an environment of corporate competitiveness on an ongoing basis, so that it can be compared with standards and achievement of job satisfaction.

The term globalization has actually been used often since the last few years. In fact, not a few business people in the world and also in Indonesia who have understood it. However, the implications of globalization on human resource management still seem to be disproportionately underestimated because their effectiveness benchmarks lack direct relevance to business strategies (Potter, 1994).

The facts show that the role of humans in supporting the implementation of a company's strategy, Strategic Business Unit and functional is very important and decisive. Many companies have carried out training and human resource development programs in response to anticipating a rapid environmental change (Potter, 1994). But what needs to be questioned is "Is the program exactly implemented?" if the answer is "yes" other questions that arise are the basis and effectiveness of the program, and the integration of the program holistically with the company's mission, vision, strategy and culture. The answer to this question is important as a basis for evaluating the effectiveness of the overall development program. Measuring organizational effectiveness and human resource activities need to be designed professionally. Intellectual capital and its measurement have recently been considered as a promising alternative even though implementation is not as easy as expected (Semampouw, 1999).

In the 21st century businesses must also be able to integrate all dimensions of the environment because people will "demand" corporate responsibility for these environmental factors. Capra suggests that the shift of the mechanistic paradigm to the holistic paradigm will continue on its own. Stakeholders will vary widely which among others consist of shareholders, employees, families, suppliers, customers, communities, governments, ecosystems. Profit optimization is not a major emphasis because many other factors such as $\mathrm{HR}$ and also determine the survival of the company (Semampouw, 1999).

The business world will be increasingly oriented globally even more if the implementation of free trade becomes a reality. Competition will become more stringent and world demands will increase. Hamel and Prahalad said that competition in the future could not only be carried out by the redefinition of strategy but it was also necessary to redefine the role of top management in creating a strategy because it was the role of business people in identifying future businesses, analyzing, planning, determining/formulating and implementing the right strategy very essential and determine for example through organizational transformation.

Taylor suggests several actions that must be taken in carrying out organizational transformation in order to be successful and ready to face future problems, namely: a) strectch goals which require that goals must be specific and measurable, b) vision of the future, c) a lean structure, d) a new culture that refers to professionalism, openness and group cooperation, e) quality-oriented or world-class service, f) achievement management; 
requires each individual to provide quality products and satisfying services, g) Comprehensive innovation, h) partnerships and networks (Ulrich, 1997).

\section{METHODS OF RESEARCH}

This study includes qualitative research with a positive paradigm, namely research conducted by analyzing the condition of human resources in Indonesia economically and more focused on the condition of natural objects where researchers function as key instruments. Data analysis is carried out using the inductive approach by always emphasizing more on meaning rather than generalization. The literature review presented in this study is important to deepen the research. This is intended to explain the phenomenon of the development of human resources in Indonesia towards competitive human resources in the current era of global competition.

\section{RESULTS AND DISCUSSION}

At present, human resource development is the key to the rise of Indonesia in the future, where the starting point for human resource development is to ensure the health of pregnant women, since pregnancy, infant health, toddler health and the health of children who are still in school age, because this condition is the golden age to print superior humans.

That choice must be recognized precisely and strategically. This is based on the fact that the quality of human resources owned by this nation is still low. Indicators of the level of quality of human resources can be seen from the data of the Central Statistics Agency (BPS) 2019 which mentions the proportion of population aged 15 years and over who have a high diploma of only $8.8 \%$, high school only $26.4 \%$, junior high school $21.2 \%$, elementary school the most, which is $43.7 \%$ (Zubaedah \& Rochim, 2019).

Such conditions not only affect Indonesia's readiness to face the challenges of the industrial era 4.0, but also complicate efforts to cut the vicious cycle of poverty. This also concerns the National Defense Agency. Based on the results of the LIX National Defense Education Research Force LIX, it is known that the increase in national human capital has not shown an optimal strengthening, even though Indonesian human resources have great potential. According to data compiled by the World Bank related to the Human Capital Index, Indonesia's ranking is still low with a score of only 0.53 . On the other hand the world now faces the era of disruption 4.0 which requires superior human resources (Zubaedah \& Rochim, 2019).

By ignoring the characteristics of future business (globalization), and paying attention to HR problems faced by companies in Indonesia, it is necessary to formulate and implement an appropriate HR strategy by considering management activities, among others, as follows:

1. HR prediction needs to be done qualitatively and quantitatively through HR research;

2. Recruitment and selection must be based on factors of ability, positive personality, highly motivated, values that support the mission, vision and future strategies, for example creativity, ability to change rapidly, potential to develop, as well as the ability and willingness to learn continuously;

3. Orientation or induction needs to be done by basing on company culture;

4. Training and development need to refer to competencies, motivations and expected values and results must be measurable;

5. Maintenance needs to be done with due regard to the rights and obligations of employees carefully. Compensation which is based on an effective and fair consideration. Incentives or benefits must be carefully considered and based on merit;

6. Performance appraisals need to really assess employee performance appropriately and are oriented towards employee development; 
7. Instilling values that emphasize the paradigm of learning organization, and organizational culture oriented to professionalism;

8. Paying attention to external factors-strategy of the company that is globally oriented, business environment and others;

9. Employee career paths need to be carefully planned and transparently communicated;

10. The organizational structure should tend to be lean and flexible and encourage lateral communication and empowerment.

Challenges in Creating Competitiveness of Indonesian Human Resources. At present the company's competitiveness no longer lies in excellence in product and process technology or has a protected and regulated market, or has capital but rather in the possession of quality human resources. Human resources are assets that are difficult to trade or emulate, rare, suitable that provide a company's competitive advantage on an ongoing basis. This opinion was also raised by the CEO of General Electric, Jack Welch, who stated that the only way General Electric competed was the superiority of human resources. Likewise, the CEO of Chhrysler Corp and Unilever NV said that emphasizing human resources as capital in the face of globalization (Schuler \& Jackson, 1997).

The importance of the role of human resources as the main basis for an organization in gaining competitive advantage is due to environmental changes that create new challenges for the organization. There are 8 competitive challenges facing organizations today and in the future, viz (Ulrich, 1997):

1. Globalization. Globalization is a state full of diversity, ambiguity and complexity or a unified world without limits. In this challenge context, an organization must be able to improve the ability to learn and work together, manage differences, and complexity. An important role in the global human resource management function is the ability to increase adaptation and coordination. Consequently, a country or company long-term strategy is needed to anticipate and respond to changes to be more competitive in the world market;

2. Intellectual Capital and Competence. Competence and intellectual capital require organizations to obtain human resources who have the expertise, perspective and experience in managing global business;

3. Profitability throught cost and growth. Each organization is required to obtain profitability through efficiency or savings in production costs, human resource costs and other expenses. On the other hand to increase revenue growth by attracting users and always innovative in creating new products or services;

4. Technology. The existence of technology results in faster production processes and a smaller world. This challenge requires managers to be able to make the technology offered easy to use and useful;

5. Capability. Capability involves tangible capabilities such as technology owned and intangible capabilities such as the ability to change, flexible, have confidence and achievement motivation and others;

6. Change, change and change some more. Organizations must always change continuously to improve performance, innovate continuously and create new strategies to meet the needs and desires of users;

7. Value chain for business competitivess and HR services. User-oriented value chain;

8. Turnround is not transformation.

Development of human resources or human resources development (HRD) macro is a process of improving the quality or ability of humans in order to achieve a process of improving the quality or ability of humans in order to achieve a goal of national development. And micro, in the sense that in a work unit environment (departments or other institutions), the resources in question are workers, employees or employees. In other words human 
resource development is a process of planning education, training and management of personnel or employees to achieve an optimal result (Notoatmodjo, 1998).

Organizations that will survive could be a company that's able to foster commitment for all human creatures within the organization to memorize and proceed to memorize. The Organization Learning is related to the learning handle, whether it is related to formal and informal instruction that can grow the capacity and can create self potential. It is trusted that within the application of learning, there's a predominant psychomotor perspective (expertise) or know-how that combines cognitive (mental) and full of feeling (passionate control) perspectives, which in turn can upgrade the degree and competence of people, organizations and eventually the presence of a country within the eyes of the worldwide world.

Agreeing to Schuler and Youngblood in Rivai emphasized that examining human asset improvement from organization, human being as portion of organization so unveiled that human asset advancement in an organization will include different variables that's instruction and preparing. Agreeing to Dessler in Imprison preparing gives modern or existing representatives the skills they have to be carry out the work. In other words, preparing centers on the skills required to carry out the current work, whereas advancement may be a long-term work out, the objective being to create current or future workers for up and coming organizational work or to resolve organizational issues. Work out is more on work prerequisite / ability issues, whereas improvement centers not as it were on abilities or work requests but moreover on inspiration and behavior

Ahmad Sanusi stated that if the last century was called the century of product / service quality, then today is the century of quality of human resources. Quality human resources and the development of quality human resources are no longer rhetorical issues or themes, but rather are bets or mainstays and tests of every individual, group, community, and even each nation (Sanusi, 1998).

HR development is a lifelong process covering various fields of life. When viewed from an economic point of view, improving the quality of human resources is more enhanced in the mastery of the knowledge, skills and technology needed by the world of work in an effort to increase the efficiency and effectiveness of the production process and maintain economic balance. While the development of quality human resources is a contextual process, so that the development of human resources through educational efforts is not limited to preparing people who master knowledge and skills that are suitable for the world of work, but also people who are able, willing, and ready to learn for life (Ansori, 2015).

The program to improve the quality of human resources through education will provide benefits to institutions in the form of productivity, morale, work efficiency, stability, and institutional flexibility in anticipating the environment, both from within and from outside the institution concerned. The function and orientation of education and improving the quality of human resources have been made in a National Education Ministry policy in three main strategies for national education development, namely:

1) Equal distribution of educational opportunities;

2) Increasing the relevance and quality of education;

3) Improving the quality of education management (Harun, 2003).

Improving the Quality of Human Resources in order to have Competitiveness through Education. Education is a very important institution that plays an active role in instilling the nation's character as a common goal. Therefore, through education it is expected that the cultivation of the nation's character can be done on students who are the nation's next generation. The existence and role of educators in the learning process cannot be replaced by anyone and anything. Educators who are reliable, professional and highly competitive, and have a strong and intelligent character are the basic capital in realizing quality education that is capable of producing high-quality, intelligent, and moral human resources. Approach to work training and experience can be done jointly in the form of apprenticeship and on the 
job training. The path of work experience can be well developed if a person has the basics of knowledge, skills and skills acquired from the formal education and training path. These three channels are conducted as an effort to improve or develop the quality of human resources.

We need to realize that due to the development of contemporary science and technology today we are faced with an era of digital and cybermedia where the role of lecturers will be challenged and students are required to be smarter. In addition, the growth of various thoughts and understandings that tend to be destructive so that it can endanger the young generation. Only an intelligent and educated young generation can survive this position. In general, it can be concluded that improving the quality of human resources through character education is done through (Ansori, 2015):

- Management of education and development of human resources carried out professionally for the creation of national education goals;

- The implementation of education and human resource development by involving the government, the community and the individuals concerned;

- Curriculum development by accommodating needs in accordance with the dynamics of diverse needs;

- Making educational staff and human resource development a role model in social life.

\section{CONCLUSION}

Indonesia really needs superior human resources to navigate the globalization era due to the industrial revolution 4.0, where it requires intelligent activities, intelligent services, and innovative products. Because, there will be many types of jobs that will be affected by artificial intelligence and automation. In the future, competing competencies and capabilities from human resources will be the main agenda of company leaders to face the globalization era that continues to develop as it is today.

To be able to create and shape superior and quality Indonesian human resources, it can be done by developing character education.

\section{REFFERENCES}

1. Almasri, M. N., 2016. Manajemen Sumber Daya Manusia: Implementasi dalam Pendidikan Islam. Jurnal Penelitian Sosial Keagamaan, 19(2), pp. 133-151.

2. Ansori, A. H., 2015. Strategi Peningkatan Sumber Daya Manusia dalam Pendidikan Islam. Jurnal Qathruna, 2(2), pp. 19-56.

3. Aroef, M. \& Djamal, J. S., 2009. Grand Techno-Economic Strategy: Siasat Memicu Produktivitas untuk Memenangkan Persaingan Global. Bandung: PT. Mizan Pustaka.

4. Forum Human Capital Indonesia (2007). Excellent People Excellent Business, Pemikiran Strategik Mengenai Human Capital Indonesia. Cetakan Pertama. Jakarta: Gramedia Pustaka Utama

5. Hartanto, F. M., 2009. Paradigma Baru Manajemen Indonesia: Menciptakan Nilai dengan Bertumpu Pada Kebajikan dan Potensi Insani. Bandung: PT. Mizan Publika.

6. Harun, C. Z., 2003. Peningkatan Kualitas Sumber Daya Manusia Melalui Pendidikan Merupakan Kunci Keberhasilan Suatu Lembaga di Era Globalisasi dan Otonomi Daerah. Jurnal Pendidikan dan Kebudayaan Balitbang Diknas, 4(1), pp. 1-17.

7. Hasibuan, M. S., 1990. Manajemen Kepegawaian. 2nd' penyunt. Bandung: Alumni.

8. Mangkuprawira, Sjafri. 2008. Pengembangn SDM VS Daya Saing Global. Indosdm.

9. Notoatmodjo, S., 1998. Pengembangan Sumber Daya Manusia. Jakarta: Rineka Cipta.

10. Sanusi, A., 1998. Pendidikan Alternatif. Bandung: Grafindo Media Pratama.

11. Schuler, R. S. \& Jackson, S. E., 1997. Manajemen Sumber Daya Manusia menghadapi Abad 21. 1st penyunt. Jakarta: Erlangga. 
12. Sugiarto, E. C., 2019. Pembangunan Sumber Daya Manusia (SDM) Menuju Indonesia Unggul. [Online] Available at:

13. https://www.setneg.go.id/baca/index/pembangunan_sumber_daya_manusia_sdm_menuj u_indonesia_unggul [Diakses September 2019].

14. Tayibnapis, A. Z., Wuryaningsih, R. E. \& Gora, R., 2018. Indonesia's Efforts to Achieve Globally Competitive Human Resources. International Journal of Humanities and Social Science Invention (IJHSSI), 7(8), pp. 1-6.

15. Ulrich, D., 1997. Human Resources Champion: The Next Agenda For Adding Value and Dlivering Results. 1st penyunt. Boston: Harvard Business School Press.

16. Weinberg, R. S. \& Gould, D., 2011. Foundation of Sport and Exercise Psycology. 1st penyunt. Champaign, Illinois: Human Kinetics.

17. Zubaedah, N. \& Rochim, A., 2019. Membangun SDM Wujudkan Indonesia Unggul. [Online] Available at: https://nasional.sindonews.com/read/1430422/15/membangun-sdmwujudkan-indonesia-unggul-1565917612 [Diakses September 2019]. 